九州大学学術情報リポジトリ

Kyushu University Institutional Repository

\title{
Contamination of the Summer and Winter Vegetables by Heavy Metals in a Multi-Industry District of Bangladesh
}

AHMED, Minhaz

Graduate School of Integrated Sciences for Global Society, Kyushu University

MATSUMOTO, Masaru

Institute of Tropical Agriculture, Kyushu University

KUROSAWA, Kiyoshi

Institute of Tropical Agriculture, Kyushu University

https://doi.org/10.5109/2558883

出版情報: 九州大学大学院農学研究院紀要. 65 (1)，pp.9-14，2020-02. Faculty of Agriculture， Kyushu University

バージョン :

権利関係 : 


\title{
Contamination of the Summer and Winter Vegetables by Heavy Metals in a Multi-Industry District of Bangladesh
}

\author{
Minhaz AHMED ${ }^{1}$, Masaru MATSUMOTO* and Kiyoshi KUROSAWA
}

Institute of Tropical Agriculture, Kyushu University, Fukuoka, 819-0395, Japan

(Received October 10, 2019 and accepted November 14, 2019)

\begin{abstract}
Heavy metal $(\mathrm{Cr}, \mathrm{Cu}, \mathrm{Zn}, \mathrm{As}, \mathrm{Cd}$, and $\mathrm{Pb}$ ) contamination of the summer and winter vegetables were examined in a multi-industry district of Bangladesh. In this district, various kinds of industries discharged their wastewater into nearby irrigation canals, contaminating the vegetables that were cultivated by using the irrigation water with the heavy metals. Among the vegetables, the heavy metal concentrations were the highest in root vegetables, followed by leaf vegetables for both the summer and winter vegetables. Zn was the highest, while Cd was the lowest in concentrations throughout the vegetables. Every heavy metal concentration was lower in the summer than in the winter vegetables. The reason is probably that the concentrations of irrigation water and soil were diluted by rainfall during the rainy season when the summer vegetables were grown. The health risk index, which enables to assess the potential health risk due to the ingestion of vegetables, showed a high value in root and leaf vegetables, which indicated that the root and leaf vegetables grown in the district were found unsuitable for human ingestion.
\end{abstract}

Key words: Industrial wastewater, vegetables, contamination, season, health risk index

\section{INTRODUCTION}

Contamination of agricultural soil with heavy metals is a serious environmental concern in developing countries due to its acute and persistent toxicity (A Özdel, 2014). In recent decades, the anthropogenic activities like industrialization and urbanization have led to an increase in heavy metal and metalloid concentrations in water, soil and vegetables (Islam et al., 2017). In Bangladesh, food safety is a prime issue for securing health, where various crops are assumed to be contaminated with carcinogenic ( $\mathrm{Pb}, \mathrm{As}$, and $\mathrm{Cd}$ ) and non-carcinogenic (Fe, Co, V, Cu, Zn, Cr, Mn, and Ni) heavy metals and are unsafe for human ingestion (Sultana et al., 2017). Unplanned industrialization and urbanization in the country have led to discharge the heavy metal contaminated wastewater into water bodies and soil, and as a result, vegetables grown there became contaminated with heavy metals, and the vegetables were consumed by many people by transportation and retailing (Ikeda et al., 2000). The contaminated crop products have caused a health concern due to its severe harmful impacts (Sultana et al., 2014). When vegetables are produced in a contaminated soil, heavy metals can be stored in the edible parts of the vegetables that causes toxicity in the vegetables (Sharma et al., 2009). Heavy metals are non-biodegradable in nature and once heavy metals are accumulated in organs of human body, it causes severe disorders in the organs (Duruibe et al., 2007). According to the World Bank report, about one million populations are at a health risk in Bangladesh due to toxicity of heavy metal especially by lead (The Daily Star, 2018).

\footnotetext{
Graduate School of Integrated Sciences for Global Society, Kyushu University, Fukuoka, 819-0395, Japan

* Corresponding author (E-mail: mmatsu@agr.kyushu-u.ac.jp)
}

The farmland of Gazipur District, Bangladesh was selected for the present study, where various industries, including garment, textile, dyeing, ceramic, pharmaceutical, paint, and packaging industries, discharge their wastewater into nearby waterbodies without any treatment and which cause heavy metal contamination in the surrounding environment. Farmers use the heavy metal contaminated irrigation water for growing vegetables, which is the major cause of heavy metal contamination in vegetables in the district. Most of the produced vegetables are marketed in the capital Dhaka and are consumed by many people. The vegetables may be contaminated severely with heavy metals ( $\mathrm{Cr}, \mathrm{Cu}, \mathrm{Zn}, \mathrm{Cd}$, As, $\mathrm{Hg}, \mathrm{Pd}, \mathrm{Fe}$, and $\mathrm{Ni}$ ) according to the earlier studies (Barakat, 2011; Sultana et al., 2011). Here, the risk of intake of contaminated vegetables on human health was examined. Therefore, this study aimed to clarify the contamination levels of $\mathrm{Cr}, \mathrm{Cu}, \mathrm{Zn}, \mathrm{As}, \mathrm{Cd}$ and $\mathrm{Pb}$ for the summer and winter vegetables. Further, the potential health risk due to vegetables consumption was assessed by considering health risk index (HRI) of heavy metals. In this district, different types of the summer and winter vegetables are cultivated in the rainy and dry seasons, respectively.

\section{MATERIALS AND METHODS}

\section{Study area}

The study area of Gazipur District is a suburban industrial area located about $50 \mathrm{~km}$ away north from the capital Dhaka. The district has an area of $1,806 \mathrm{~km}^{2}$ with a population of 3.4 million (BBS, 2011). The district has a flat lowland topography with an elevation of 4-24 m (Shapla et al., 2015). The soils are acid basin clays with nutrient-poor characteristics, i.e., deficient in organic matter, phosphate, nitrogen and lime (UNDP/FAO, 1988). The annual average rainfall is $2,036 \mathrm{~mm}$ (Merkel, 2012), the rainy season is from April to October, and dry 
season from November to March. The annual average air temperature is $25.8^{\circ} \mathrm{C}$ (Merkel, 2012).

The target areas in the district are Banglabazar, Kashimpur, and Chandra, where various kinds of smallscale factories are located (Fig. 1). The main industries are different from area to area, i.e., in Banglabazar, textile, dye, battery, metallurgical and ceramics industries are located; in Kashimpur, plastic, garments and agrochemical industries, and in Chandra, pharmaceutical, agrochemical, fabric printing, poultry feed, and fish feed industries are located, respectively (Ahmed et al., 2018; Ahmed et al., 2019). In the respective areas, industrial wastewater is discharged from the factories into nearby irrigation canals throughout the year.

\section{Sampling of vegetables}

The sampling locations were shown in Fig. 1. The sampling location was the same in summer and winter vegetables. For the summer vegetables, taro (Colocasia esculenta), water spinach (Ipomoea reptans), helencha (Enhydra fluctuans), eggplant (Solanum melongena), and sponge gourd (Luffa acutangula) were sampled in June-July, 2015. While for the winter vegetables, radish (Raphanus raphanistrum subsp. sativus), amaranth (Amaranthus lividus), red amaranth (Amaranthus gangeticus), spinach (Spinacia oleracea), indian spinach (Basella alba), pumpkin (Cucurbita moschata), bottle gourd (Lagenaria siceraria), taro (Colocasia esculenta), and yard long bean (Vigna sesquipedalis) were sampled in NovemberDecember, 2017. Then the samples were cleaned with tap water followed by deionized water. The samples were then divided into root, stem, fruit and leaf parts and these parts were first air dried and then oven dried at $60^{\circ} \mathrm{C}$ for 48 hours and were milled uniformly with a grinder.

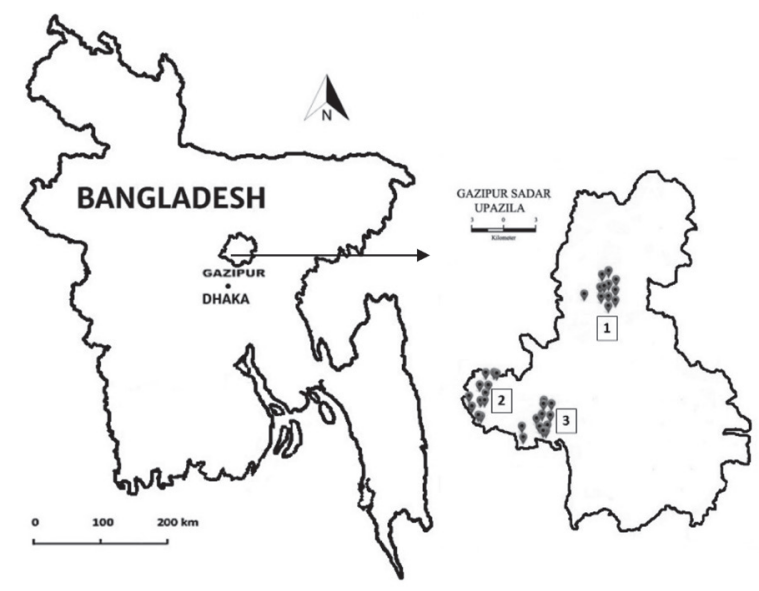

Fig. 1. Sampling locations of the summer and winter vegetables in Gazipur District, Bangladesh. 1. Banglabazar; 2. Chandra, 3. Kashimpur.

\section{Sample analysis}

For the digestion of vegetable samples, the UWLAB method (UWLAB, 2005) was applied. Oven dried $0.5 \mathrm{~g}$ of the samples was taken into $50 \mathrm{ml}$ test tube. Five $\mathrm{ml}$ of concentrated nitric acid $\left(65 \% \mathrm{HNO}_{3}\right)$ was added to the samples and soaked at room temperature for 2-3 hours. Then the test tube was placed in the block heater and heated at $130^{\circ} \mathrm{C}$ for $14-16$ hours. The mixture solution was heated again by adding $1 \mathrm{ml}$ of $30 \%$ hydrogen peroxide $\left(\mathrm{H}_{2} \mathrm{O}_{2}\right)$ for 20-30 minutes. Finally, the mixture was cooled, filtered and diluted with double deionized water to $50 \mathrm{ml}$. Heavy metal (Cr, Cu, Zn, As, Cd, and Pb) concentrations of digested solutions of vegetables were determined by inductively coupled plasma-mass spectrometry (ICP-MS; 7500 ce, Agilent Technologies, USA) at Kyushu University.

\section{Daily Intake of Heavy Metals (DIM)}

The daily intake of heavy metals through vegetables was estimated with the following equation.

$$
\mathrm{DIM}=\frac{\mathrm{C} \text { metal } \times \mathrm{C} \text { factor } \times \mathrm{D} \text { food intake }}{\mathrm{B} \text { average weight }}
$$

Where $\mathrm{C}_{\text {metal }}, \mathrm{C}_{\text {factor}}, \mathrm{D}_{\text {food intake }}$ and $\mathrm{B}_{\text {average weight }}$ represent the heavy metal concentrations in the vegetables (mg/ $\mathrm{kg}$ ), conversion factor, daily intake of vegetables $(\mathrm{Kg})$ and average body weight $(\mathrm{Kg})$, respectively. According to Rattan et al. (2005), the fresh to dry weight conversion factor of green vegetables is 0.085 . The daily intake of vegetables for adult persons was $0.1673 \mathrm{~kg}$ (BBS, 2016). The average body weight of adult person in Bangladesh was $66.5 \mathrm{~kg}$ (Khadem and Islam, 2014). These values were applied in the estimation.

\section{Health Risk Index (HRI)}

The health risk index is the quotient between daily intake of heavy metals (DIM) and their reference dose $\left(\mathrm{R}_{\mathrm{f}} \mathrm{D}\right)$, which is calculated as follows (Pierzynski et al., 2000).

$$
\mathrm{HRI}=\frac{D I M}{R f D}
$$

Where $\mathrm{R}_{\mathrm{f}} \mathrm{D}$ represents the oral reference doses, which are 0.003, 0.04, 0.3, 0.0003, 0.0005, and 0.004 mg/ $\mathrm{kg}$ for $\mathrm{Cr}, \mathrm{Cu}, \mathrm{Zn}, \mathrm{As}, \mathrm{Cd}$, and $\mathrm{Pb}$, respectively (USEPA, 2007). HRI $>1$ means that the exposed population is assumed to be at a potential health risk.

\section{Data Analysis}

The graphical presentation and calculations of data for the heavy metal concentrations in the vegetables were implemented by the Excel software (version 2016).

\section{RESULTS AND DISCUSSION}

\section{Contamination level of heavy metals in different types of the summer and winter vegetables}

Heavy metal concentrations of the vegetables varied widely with the type of vegetables and areas, as shown in Figs. 2 and 3. In the summer vegetables (Fig. 2), the highest Zn concentration ( $114.7 \mathrm{mg} / \mathrm{kg}$ ) was observed in helencha of Banglabazar, followed by root $(66.9 \mathrm{mg} / \mathrm{kg})$ and shoot $(61.1 \mathrm{mg} / \mathrm{kg})$ of water spinach of the same area, and taro root $(66.7 \mathrm{mg} / \mathrm{kg})$ of Chandra. Taro leaf 


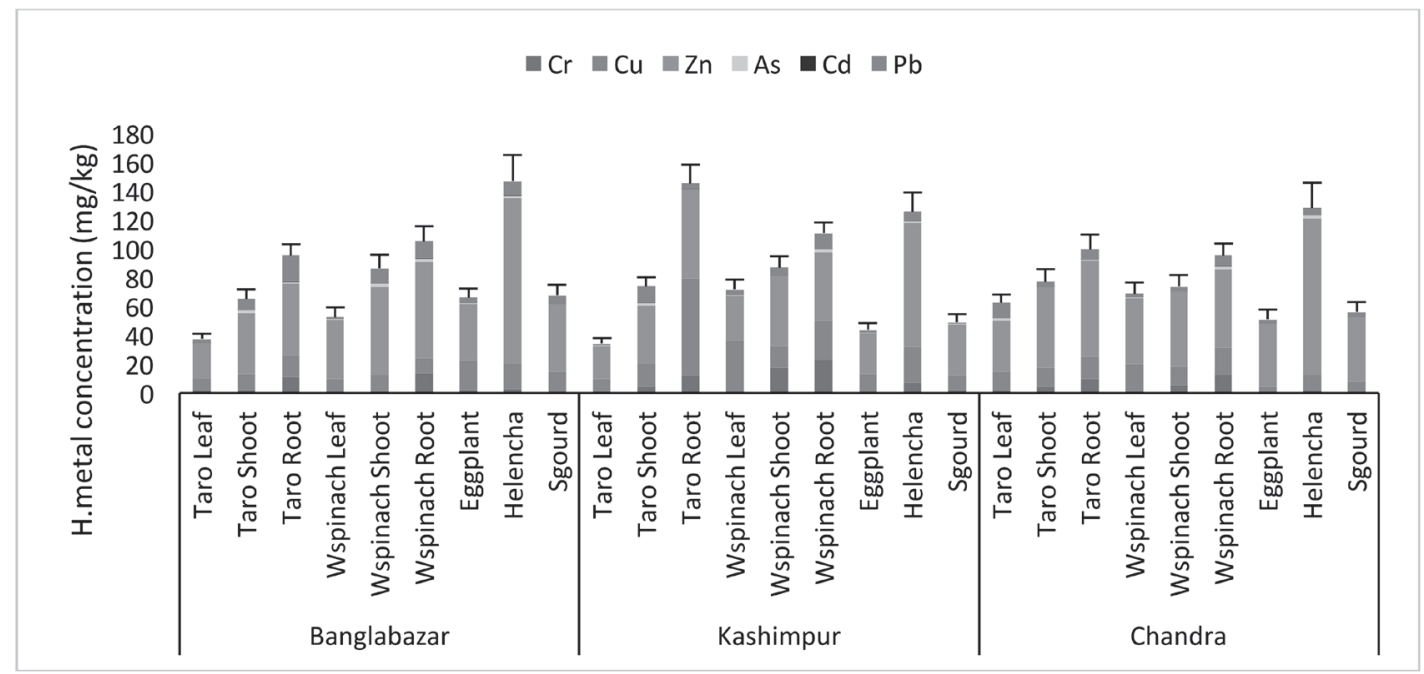

Fig. 2. Heavy metal concentrations of the summer vegetables in the respective areas.

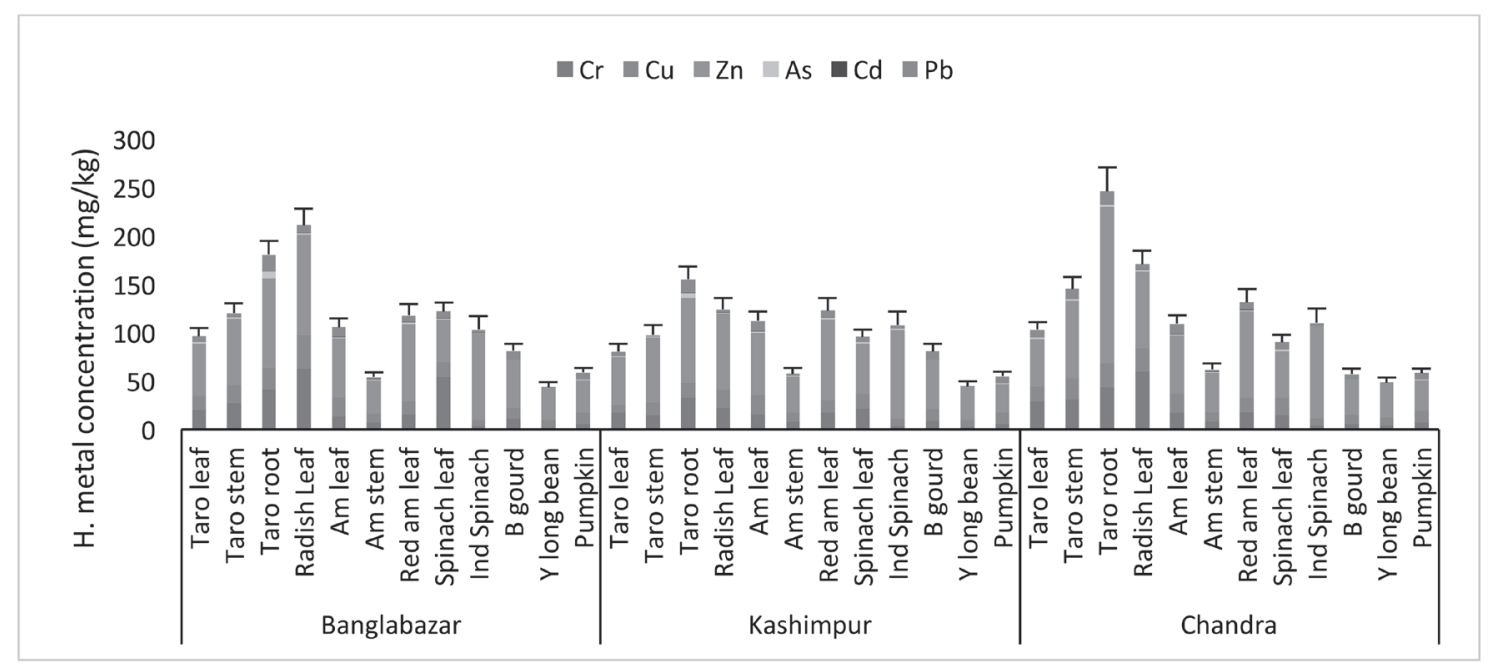

Fig. 3. Heavy metal concentrations of the winter vegetables in the respective areas.

contained the lowest Zn concentration $(22.9 \mathrm{mg} / \mathrm{kg})$ in the Kashimpur. The $\mathrm{Cr}$ and $\mathrm{Cu}$ concentrations in taro root and water spinach root were higher in Kashimpur; and the $\mathrm{Pb}$ and $\mathrm{Cd}$ concentrations were higher in Banglabazar than in the other areas. For eggplant, the concentrations of As and Cd were higher in Kashimpur and lower in Banglabazar than in the other areas. On the other hand, the $\mathrm{Cr}$ and $\mathrm{Cu}$ concentrations were high in eggplant in Banglabazar. Sponge gourd contained higher As and $\mathrm{Cd}$ concentrations in Chandra and contained lower As and Cd concentrations in Kashimpur, whereas the $\mathrm{Cu}$ and $\mathrm{Pb}$ concentrations of sponge gourd were higher in Banglabazar than in the other areas. Regarding the total concentration of all heavy metals, the highest was observed in helencha in all three areas; the second highest was in water spinach root; and very low concentrations were observed in sponge gourd, eggplant and taro leaf. The small standard error values of the concentrations in the upper part of the bar graph (Fig. 2) indicate no significant differences between the sampling locations.
For winter vegetables (Fig. 3), the highest Zn concentration $(161.36 \mathrm{mg} / \mathrm{kg})$ was observed in taro root of Chandra followed by Indian spinach $(94.54 \mathrm{mg} / \mathrm{kg})$, and by radish leaf $(103.35 \mathrm{mg} / \mathrm{kg})$ of Banglabazar. The lowest Zn concentration was observed in pumpkin (28.79 mg/kg) of Kashimpur. The highest Cr (63.55 mg/ $\mathrm{kg})$ and $\mathrm{Cu}(34.69 \mathrm{mg} / \mathrm{kg})$ concentrations were observed in radish leaf of Banglabazar; in addition, the highest As $(6.92 \mathrm{mg} / \mathrm{kg})$ and $\mathrm{Pb}(17.23 \mathrm{mg} / \mathrm{kg})$ concentrations were in taro root of Banglabazar. In Chandra, red amaranth leaf showed the highest Cd $(1.11 \mathrm{mg} / \mathrm{kg})$ concentration.

Regarding the total concentration of all heavy metals (dry season), taro root was the highest in the respective three areas, followed by radish leaf, red amaranth leaf, taro stem and Indian spinach, whereas yard long bean and pumpkin were the lowest in the respective areas. The small standard error values of the concentration in the upper part of the bar graph (Fig. 3) indicate no significant differences between the sampling locations.

In terms of the differences between root, leaf and fruit vegetables, the total heavy metal concentration was 
the highest in root vegetables, followed by leaf and then by fruit vegetables (Figs. 2 and 3 ). Root vegetables that were grown in contact with soil were thought to be more heavily contaminated than leaf and fruit vegetables. Roots of taro and water spinach grow in moist rich soils, making these vegetables to be highly contaminated with heavy metals. Soil moisture is provided by the contaminated irrigation water, and vegetable roots absorb the moisture from the soil. Heavy metals absorbed with the moisture are translocated in plant body. The absorption and translocation abilities depend on the kind of vegetables and which differentiate the heavy metal concentrations between vegetables (Islam and Hoque, 2014). The heavy metal concentrations in the summer vegetables were lower than the winter vegetables (according to paired $t$-test; $t=0.18-5.15$, df $=26, p<0.05$ ), which may be due to the effect of rainfall in diluting irrigation water for the summer vegetables growth.

\section{Estimated daily intake of heavy metals and health risk assessment}

The degree of toxicity of heavy metals to human being depends upon their daily intake (Singh et al., 2010). Long-term exposure to toxic heavy metals through the ingestion of contaminated vegetables could hamper biochemical processes (Anhwange et al., 2013). Thus, assessment of the toxicity level of vegetables heavy metal concentrations is important. Therefore, daily intake of heavy metals (DIM) was estimated and health risk index (HRI) was calculated.

For the summer vegetables (Table 1), the highest intake of $\mathrm{Cu}, \mathrm{Cd}$ and $\mathrm{Pb}$ were observed in taro. Helencha showed the highest intake of $\mathrm{Zn}$ and As, whereas water spinach exhibited the highest intake of $\mathrm{Cr}$. The DIMs of $\mathrm{Cr}, \mathrm{Cu}, \mathrm{Zn}, \mathrm{As}, \mathrm{Cd}$ and $\mathrm{Pb}$ ranged from 0.0003 to 0.0019 , from $0.0023-0.004$, from $0.0079-$ 0.022 , from $0.00003-0.00035$, from 0.000016 0.000043 , and from $0.00059-0.00156$, respectively. The order of heavy metal intake of all vegetables is $\mathrm{Zn}>\mathrm{Cu}$ $>\mathrm{Pb}>\mathrm{Cr}>\mathrm{As}>\mathrm{Cd}$.

The health risk associated with the consumption of vegetables was estimated by calculated HRI values. Regarding HRI, taro indicated the highest $\mathrm{HRI}$ of $\mathrm{Cu}, \mathrm{Cd}$ and $\mathrm{Pb}$ (Table 1). Helencha showed the highest HRI of Zn and As, whereas water spinach showed the highest
HRI of Cr. The mean HRIs were found to be higher in As (0.53) followed by $\mathrm{Cr}(0.31), \mathrm{Cu}(0.08)$ and $\mathrm{Zn}$ (0.04). The lowest HRI was observed in Cd (0.05). In total, the leaf and root vegetables exceeded the recommended HRI of larger than 1.

For the winter vegetables, the DIMs of $\mathrm{Cr}, \mathrm{Cu}, \mathrm{Zn}$, As, Cd and $\mathrm{Pb}$ ranged from $0.0007-0.0105$, from 0.0016 -0.0055 , from $0.0066-0.0196$, from $0.00004-0.00048$, from 0.000001 - 0.000229, and from 0.00008 $0.00189 \mathrm{mg} / \mathrm{kg}$ per day, respectively (Table 2). Among different winter vegetables, radish showed the maximum intake of $\mathrm{Cr}$ and $\mathrm{Cu}$, whereas Indian spinach and red amaranth showed the maximum intake of $\mathrm{Zn}$ and $\mathrm{Cd}$, respectively. Taro indicated high intake of $\mathrm{As}$ and $\mathrm{Pb}$. The mean DIM of the vegetables decreased in the order of $\mathrm{Zn}>\mathrm{Cr}>\mathrm{Cu}>\mathrm{Pb}>\mathrm{As}>\mathrm{Cd}$.

Regarding HRI (Table 2), radish showed the highest HRI of $\mathrm{Cr}$ and $\mathrm{Cu}$. Taro exhibited the maximum HRI of As and $\mathrm{Pb}$, whereas red amaranth and Indian spinach presented the maximum HRI of $\mathrm{Cd}$ and Zn. However, the highest HRI range was observed in Cr (from $0.29-$ 3.49) followed by As (from 0.29 - 1.59), $\mathrm{Cu}$ (from $0.04-$ 0.14 ) and $\mathrm{Zn}$ (from $0.02-0.07$ ). The lowest mean HRI was found in $\mathrm{Cd}$ which ranged from $0.002-0.459$ followed by $\mathrm{Pb}$ (from $0.02-0.47$ ). In total, leaf and root vegetables exceeded the recommended HRI of larger than 1. The DIM and HRI for the summer vegetables were lower than those for the winter vegetables, which may be due to the lower heavy metal concentrations of the summer vegetables.

To assess the health risk of heavy metals, it is necessary to estimate the exposure level of heavy metals by quantifying their intake by the target organisms (Khan et al., 2008). If people consumed the heavy metal contaminated crops, the people will face serious health risk. The vegetables produced in the study area are marketed in Gazipur District and Dhaka City. Therefore, the HRI for the respective vegetables still needs to be carefully monitored and assessed. The total HRI values (sum of individual heavy metal HRI) indicated much more health risk condition for the consumers when each vegetable is consumed. The total HRI for the vegetables were larger than the recommended value of HRI > 1, except for fruit vegetables in both the summer and winter vegetables. Therefore, potential health risk for root and leaf vegeta-

Table 1. DIM (mg/kg per day) and HRI for the respective summer vegetables

\begin{tabular}{|c|c|c|c|c|c|c|c|c|c|}
\hline $\begin{array}{l}\text { Division of } \\
\text { vegetables }\end{array}$ & Name & & $\mathrm{Cr}$ & $\mathrm{Cu}$ & $\mathrm{Zn}$ & As & $\mathrm{Cd}$ & $\mathrm{Pb}$ & Total \\
\hline \multirow[t]{6}{*}{ Root and Leaf } & $\operatorname{Taro}(n=9)$ & DIM & 0.0012 & 0.0040 & 0.0095 & 0.00016 & 0.000043 & 0.00156 & 0.016 \\
\hline & & HRI & 0.40 & 0.10 & 0.03 & 0.54 & 0.09 & 0.39 & 1.55 \\
\hline & Water spinach $(n=9)$ & DIM & 0.0019 & 0.0038 & 0.0107 & 0.00021 & 0.000019 & 0.00136 & 0.018 \\
\hline & & HRI & 0.63 & 0.09 & 0.04 & 0.69 & 0.04 & 0.34 & 1.83 \\
\hline & Helencha $(n=3)$ & DIM & 0.0009 & 0.0038 & 0.0220 & 0.00035 & 0.000029 & 0.00151 & 0.029 \\
\hline & & HRI & 0.30 & 0.09 & 0.07 & 1.17 & 0.06 & 0.38 & 2.08 \\
\hline \multirow[t]{4}{*}{ Fruit } & Eggplant $(n=3)$ & DIM & 0.0003 & 0.0026 & 0.0079 & 0.00003 & 0.000016 & 0.00059 & 0.011 \\
\hline & & HRI & 0.11 & 0.07 & 0.03 & 0.12 & 0.03 & 0.15 & 0.50 \\
\hline & Sponge gourd $(n=3)$ & DIM & 0.0003 & 0.0023 & 0.0091 & 0.00003 & 0.000016 & 0.00069 & 0.012 \\
\hline & & HRI & 0.09 & 0.06 & 0.03 & 0.11 & 0.03 & 0.17 & 0.50 \\
\hline
\end{tabular}

n: number of samples 
Table 2. DIM (mg/kg per day) and HRI for the respective winter vegetables

\begin{tabular}{|c|c|c|c|c|c|c|c|c|c|}
\hline $\begin{array}{l}\text { Division of } \\
\text { vegetables }\end{array}$ & Name & & $\mathrm{Cr}$ & $\mathrm{Cu}$ & $\mathrm{Zn}$ & As & $\mathrm{Cd}$ & $\mathrm{Pb}$ & Total \\
\hline \multirow[t]{14}{*}{ Leaf } & Radish Leaf $(n=6)$ & DIM & 0.0105 & 0.0055 & 0.0186 & 0.00030 & 0.000125 & 0.00111 & 0.036 \\
\hline & & HRI & 3.49 & 0.14 & 0.06 & 1.00 & 0.250 & 0.28 & 5.22 \\
\hline & Amaranth $(n=12)$ & DIM & 0.0026 & 0.0032 & 0.0104 & 0.00025 & 0.000111 & 0.00130 & 0.018 \\
\hline & & HRI & 0.86 & 0.08 & 0.03 & 0.85 & 0.223 & 0.33 & 2.37 \\
\hline & Red Amaranth $(n=6)$ & DIM & 0.0038 & 0.0030 & 0.0179 & 0.00029 & 0.000229 & 0.00139 & 0.027 \\
\hline & & HRI & 1.26 & 0.07 & 0.06 & 0.98 & 0.459 & 0.35 & 3.18 \\
\hline & Spinach $(n=6)$ & DIM & 0.0066 & 0.0035 & 0.0102 & 0.00029 & 0.000098 & 0.00136 & 0.022 \\
\hline & & HRI & 2.20 & 0.09 & 0.03 & 0.95 & 0.197 & 0.34 & 3.81 \\
\hline & Indian spinach $(n=6)$ & DIM & 0.0009 & 0.0016 & 0.0196 & 0.00020 & 0.000036 & 0.00062 & 0.023 \\
\hline & & HRI & 0.29 & 0.04 & 0.07 & 0.67 & 0.072 & 0.15 & 1.29 \\
\hline & Pumpkin $(n=6)$ & DIM & 0.0014 & 0.0027 & 0.0066 & 0.00009 & 0.000017 & 0.00155 & 0.012 \\
\hline & & HRI & 0.48 & 0.07 & 0.02 & 0.29 & 0.034 & 0.39 & 1.28 \\
\hline & Bottle gourd $(n=6)$ & DIM & 0.0020 & 0.0024 & 0.0095 & 0.00009 & 0.000024 & 0.00170 & 0.016 \\
\hline & & HRI & 0.65 & 0.06 & 0.03 & 0.29 & 0.049 & 0.42 & 1.51 \\
\hline \multirow[t]{2}{*}{ Root and leaf } & $\operatorname{Taro}(n=18)$ & DIM & 0.0062 & 0.0037 & 0.0168 & 0.00048 & 0.000041 & 0.00189 & 0.029 \\
\hline & & HRI & 2.08 & 0.09 & 0.06 & 1.59 & 0.082 & 0.47 & 4.38 \\
\hline \multirow[t]{2}{*}{ Fruit } & Yard long bean $(n=6)$ & DIM & 0.0007 & 0.0018 & 0.0072 & 0.00004 & 0.000001 & 0.00008 & 0.010 \\
\hline & & HRI & 0.22 & 0.05 & 0.02 & 0.12 & 0.002 & 0.02 & 0.43 \\
\hline
\end{tabular}

n: number of samples

bles are of high health concern.

\section{CONCLUSIONS}

Heavy metal concentrations were higher in root and leaf vegetables than in fruit vegetables in both the summer and winter vegetables. Moreover, the heavy metal concentrations were lower in the summer than in the winter vegetables, for which dilution of irrigation water by rainfall during the summer vegetables growing period was perhaps responsible. The total HRIs for root and leaf vegetables were larger than 1 , except for fruit vegetables in both the summer and winter vegetables. Therefore, the root and leaf vegetables produced from the study area are considered to have a high health risk and unsuitable for human ingestion.

\section{ACKNOWLEDGEMENTS}

The authors are grateful to the authorities of Bangabandhu Sheikh Mujibur Rahman Agricultural University, Bangladesh, and Kyushu University, Japan for providing laboratory facilities during the research period. Special thanks to Dr. Akinori Ozaki, Assistant Professor of the Institute of Tropical Agriculture, Kyushu University for his support of samples import from Bangladesh to Japan under the permission of Japanese Government.

\section{AUTHOR CONTRIBUTIONS}

Conceptualization and design, M. Ahmed and K. Kurosawa; Methodology and analysis and writing original draft, M. Ahmed; Investigation and supervision, K. Kurosawa and M. Matsumoto; Review and editing, M. Ahmed, M. Matsumoto and K. Kurosawa

\section{REFERENCES}

Ağca, N. and E. Özdel 2014 Assessment of spatial distribution and possible sources of heavy metals in the soils of SarisekiDörtyol District in Hatay Province (Turkey). Environ. Earth. Sci., 71: 1033-1047. doi: 10.1007/s12665-013-2507-8

Ahmed, M., Matsumoto, M. and K. Kurosawa 2018 Heavy Metal Contamination of Irrigation Water, Soil, and Vegetables in a Multi-industry District of Bangladesh. Int. J. Environ. Res., 12: 531-542. doi: 10.1007/s41742-018-0113-Z

Ahmed, M., Matsumoto, M., Ozaki, A. and N. V. Thinh 2019 Heavy Metal Contamination of Irrigation Water, Soil , and Vegetables and the Difference between Dry and Wet Seasons Near a Multi-Industry Zone. Water, 11: 583. doi: 10.3390/w11030583

Anhwange, B., Agbaji, E., Gimba, C. and V. Ajibola 2013 Seasonal Variations in Trace Metals Contents of Some Vegetables Grown on Irrigated Farmlands along the Bank of River Benue within Makurdi Metropolis. J. Nat. Sci. Res., 3: 74-82

Barakat M. A. 2011 New trends in removing heavy metals from industrial wastewater. Arab. J. Chem., 4: 361-377. doi: 10.1016/j.arabjc.2010.07.019

BBS 2011 District Statistics Gazipur. Bangladesh Bureau of Statistics, Statistics and Informatics Division, Ministry of Planning, Government of the People's Republic of Bangladesh, Dhaka

BBS 2016 Preliminary report on household income and expenditure survey. Bangladesh Bureau of Statistics, Statistics and Informatics Division, Ministry of Planning, Government of the People's Republic of Bangladesh, Dhaka

Duruibe, J. O., Ogwuegbu, M. O. C. and J. N. Egwurugwu 2007 Heavy metal pollution and human biotoxic effects. Int. J. Phys. Sci., 2: 112. doi: 10.1016/j.proenv.2011.09.146

Ikeda, M., Zhang, Z. W., Shimbo, S., Watanabe, T., Nakatsuka, H., Moon, C., Matsuda-Inoguchi, N. and K. Higashikawa 2000 Urban population exposure to lead and cadmium in east and south-east Asia. Sci. Total. Env., 249: 373-384. doi: 10.1016/ S0048-9697(99)00527-6

Islam, M. S. and M. Hoque 2014 Concentrations of heavy metals in vegetables around the industrial area of Dhaka city, Bangladesh and health risk assessment. Int. Food. Res. J., 21: 21212126

Islam, M. S., Ahmed, M. K., Habibullah-Al-Mamun, M. and S. M. A. Islam 2017 Sources and Ecological Risk of Heavy Metals in Soils of Different Land Uses in Bangladesh. Pedosphere. doi: 10.1016/S1002-0160(17)60394-1

Khadem, M. M. and M. A. Islam 2014 Development of anthropo- 
metric data for Bangladeshi male population. Int. J. Ind. Ergon., 44: 407-412. doi: 10.1016/j.ergon.2014.01.007

Khan, S., Cao, Q., Zheng, Y.M., Huang, Y. Z. and Y. G. Zhu 2008 Health risks of heavy metals in contaminated soils and food crops irrigated with wastewater in Beijing, China. Environ. Pollut., 152: 686-692. doi: 10.1016/j.envpol.2007.06.056

Merkel, A. 2012 Climate data.org. https://en.climate-data.org/ asia/bangladesh/dhaka-division/gazipur-969817/\#climate-graph. (Accessed on 20 January 2019)

Pierzynski, G. M., Sims, J. T. and G. F. Vance 2000 Soils and Environmental Quality, Second. CRC Press, LLC, NW Corporate Blvd., Boca Raton, FL

Rattan, R. K., Datta, S. P., Chhonkar, P. K., Suribabu, K. and A. K. Singh 2005 Long-term impact of irrigation with sewage effluents on heavy metal content in soils, crops and groundwater-a case study. Agric. Ecosyst. Environ., 109: 310-322. doi: 10.1016/j.agee.2005.02.025

Shapla, T., Park, J., Hongo, C. and H. Kuze 2015 Agricultural Land Cover Change in Gazipur, Bangladesh, in Relation to Local Economy Studied Using Landsat Images. Adv. Remote. Sens., 4: $214-223$

Sharma, R. K., Agrawal, M. and F. M. Marshall 2009 Heavy metals in vegetables collected from production and market sites of a tropical urban area of India. Food. Chem. Toxicol., 47: 583591. doi: 10.1016/j.fct.2008.12.016

Singh. A., Sharma. R. K., Agrawal, M. and F. M. Marshall 2010 Health risk assessment of heavy metals via dietary intake of foodstuffs from the wastewater irrigated site of a dry tropical area of India. Food. Chem. Toxicol., 48: 611-619. doi: 10.1016/j.fct.2009.11.041

Sultana, M. S., Islam, M. S., Rahman, S. and M. A. Al-Mansur 2011 Study of Surface Water and Soil Quality Affected by Heavy Metals of Pabna Sadar. Bangladesh. J. Sci. Ind. Res., 46: 133-140

Sultana, M. S., Jolly, Y. N., Yeasmin, S., Islam, A., Satter, S. and S. M. Tareq 2014 Transfer of Heavy Metals and Radionuclides from Soil to Vegetables and Plants in Bangladesh. Elsevier Inc

Sultana, M. S., Rana, S., Yamazaki, S., Aono, T. and S. Yoshida 2017 Health risk assessment for carcinogenic and non-carcinogenic heavy metal exposures from vegetables and fruits of Bangladesh. Cogent. Environ. Sci., 3: 1-17. doi: 10.1080/23311843.2017.1291107

The Daily Star 2018 Pollution the killer. https://www.thedailystar.net/environ-ment/environment-pollution-in-dhaka-bangladesh-18000-died-world-bank-report-1634566. (Accessed on 21 January 2019)

UNDP/FAO 1988 Agro-ecological regions of Bangladesh. In: Technical report-2, (BDG/81/035) FAO. Rome, Italy, p 570

USEPA 2007 Integrated risk information system. http://www. epa.gov/iris/subst

UWLAB 2005 Analysis of major, minor, and trace elements in plant tissue samples with ICP-OES and ICP-MS. In: Soil and Plant Analysis Laboratory, University of Wisconsin. Madison 